UDC 622.831 .3

I. G. Sakhno ${ }^{1}$, Dr. Sc. (Tech.), Assoc. Prof., orcid.org/0000-0002-8592-0572,

A.V. Molodetskyi², Cand. Sc. (Tech.), orcid.org/0000-0002-8457-9640,

S.V.Sakhno, orcid.org/0000-0003-3917-9143
DOI: $10.29202 /$ nvngu/2018-5/4

1 - State Higher Educational Institution "Donetsk National Technical University”, Pokrovsk, Ukraine, e-mail: ivan.sakhno@donntu.edu.ua

2 - Institute for Physics of Mining Processes National Academy of Sciences of Ukraine, Dnipro, Ukraine

\title{
IDENTIFICATION OF MATERIAL PARAMETERS FOR NUMERICAL SIMULATION OF THE BEHAVIOR OF ROCKS UNDER TRUE TRIAXIAL CONDITIONS
}

Purpose. Development a modified model of geomaterials for numerical simulation of the behavior of rocks in a true triaxial stress field.

Methodology. The research was conducted on specimens of coal grade "C". Input parameters of materials for basic models in the modeling by the finite element method were taken from the physical experiment. The experiment was conducted on the installation of true triaxial compression. The results of comparative studies on the behavior of rocks in the true triaxial stress field using the experimental method and numerical mathematical modeling are presented. Modeling is conducted by the finite element method in Ansys Inc software. The results of tests on the strength of coal specimens in generalized compression conditions are taken as in-situ properties.

Findings. It is established that use of classical deformation models - the elastic model and Drucker-Prager model - with numerical mathematical modeling of geomechanical processes is in error when describing the behavior of geomaterials in a volumetric field of stress of 30-15\% relative to the experiment. In this case, modeling with the use of an elastic model does not only cause a significant quantitative error, but also fails to reflect the quality of the dependence of the Young module and the volume compression module on average stresses at all stages of the strain. To adequately imitate the model of geomaterials, one must take into account the anisotropy of the elastic modulus, the shear modulus and the coefficient of transverse deformation, as well as the functional dependence of the dilation from the plastic deformation and the coefficient of rigidity.

Originality. The Drucker-Prager model was modified by taking into account the anisotropy of coal properties. Depending on the "average stress-average deformation", the calculation error for the elastic model is $33 \%$, for the Drucker-Prager model it is $15 \%$, while for the modified Drucker-Prager model it is $0.14 \%$.

Practical value. Using the results of the study can improve the accuracy of the prediction the stress-strain state of geomechanical objects.

Keywords: finite element method, geomaterial modeling, elastic model, Drucker-Prager model, stress, deformation

Introduction. Solving a large range of complex geomechanical problems is connected with the necessity of forecasting the destruction of rocks in the course of technological processes of development of minerals, which today is hardly thinkable without the use of a powerful mathematical apparatus.

Analytical approaches based on borrowing solutions known in classical solid-state physics, theoretical mechanics, and material resistance remained in the last century. The classical theory of strength does not allow predicting the critical state of the rock mass correctly. This is primarily due to the lack of result precision and too large degree of idealization processes in question. For more than 20 years, the main instrument for analyzing the stress-strain state (SSS) of structures, materials, elements of building structures and rock masses has involved numerical simulation methods implemented in special software packages. The most popular ones are software products where analysis is conducted using the finite element method (FEM), boundary element and discrete elements.

The use of such packages in geomechanics allows for complex geometry, geometric and physical nonlinearity

(C) Sakhno I. G., Molodetskyi A. V., Sakhno S. V., 2018 to be taken into account, calibrate the models, which ensures taking into account the heterogeneity of the properties of rocks and conducting probabilistic statistical estimates.

Analysis of the recent research. Most of mathematical research is conducted on the strength of real geomaterials to standard models incorporated in software products. This behavior of the material in the numerical models and in-situ varies, which causes deviation of calculations from the fact. Such a replacement is valid only when the accuracy of calculations is within the permissible range for the tasks of the selected type. Therefore, numerical modeling always requires additional studies to assess the accuracy and, if necessary, adjustment models; unfortunately, it is not always performed. One of the most difficult types of geomechanical problems are requiring assessment of stress-strain state array in 3-D. 3D modeling of the top-coal-caving mechanism [1], analysis of stress-strain state coal barrier pillars in tailgate [2], analysis of deformations and stresses in the goaf of longwall panels [3], stress distribution around a longwall face [4] are the tasks most relevant in the present. An attempt to identify material parameters for similar tasks is presented in this article. 
The most common models of rocks in numerical analysis are the Elastic model and the Drucker-Prager (DP) model of plasticity.

Calculations based on the assumption of the linear elasticity of rocks modeling materials are the most common in the analysis of SSS in geomechanics. Linearelastic material (Elastic model) ratio is subject to Hooke's law and does not retain deformation after removal of load. Correct description of geomechanical processes can be achieved with the solution of linear elastic problems because these processes are nonlinear in nature [5].

Drucker-Prager plasticity model is more popular, it allows us to describe satisfactorily the behavior of soils under unrestricted deformations [6-8] and the behavior of rocks under axial loading [9, 10]. Estimation of the accuracy of this model for volume loading of rocks in the scientific literature is not paid enough attention.

However, existing studies on concrete behavior [11] have shown that the Drucker-Prager model of plasticity allows precisely simulating the SSS of concrete in the conditions of the spatial limitation of deformations, which provokes the emergence of a trivial stressed state in structural elements. However, the accuracy of the model depends largely on adequate evaluation of its parameters [12]. Such a model should include pressure dependence, dependence on the trajectory, non-associative flow rule, strain hardening and limited tensile strength characteristics.

It has been demonstrated by [13] that the behavior of specific structural elements can be well estimated using a Drucker-Prager model of plasticity, in which the parameters related to friction angle and cohesion govern the yielding and hardening criteria, while the parameter related to plastic dilation determines the flow rule. Investigation of the results of tests of flat concrete columns in the theoretical framework of the Drucker-Prager model allowed establishing that the rule of hardening/ softening is regulated by plastic deformations and the coefficient of stiffness; the friction angle slightly decreases with increasing plastic deformation; and the angle of plastic dilatation is a function of axial plastic deformation and a rigidity coefficient [12].

Obtaining these relationships and functions is possible only through statistical analysis of the results of laboratory experiments on specimens. In addition to the above, when modeling the behavior of rocks one should be aware that they are defect bodies, anisotropic in-site and are uneven components in array in conditions of true triaxial stress field. Elastic constants species are not absolute constants, they depend on the type of stress state and the load [14].

Problem statement. Taking into account the abovementioned identification the parameters of the models of materials that would allow describing the behavior of geomaterials in their volume load correctly, is an important scientific and practical task, the solution of which will increase the accuracy of numerical simulation of geomechanical processes and forecast of critical state of rocks. In addition, in this article, an attempt is made to modify Drucker-Prager's basic model to improve the accuracy results of calculations. The estimation of the accuracy of developed models was carried out by comparing the results of the calculation and the experiment.
Research method. A series of physical experiments was conducted to obtain the initial data for mathematical modeling on the installation of unequal component triaxial compression (UCTC), which was developed and used in the Institute of Physics Rocks of the National Academy of Sciences of Ukraine [15]. This test machine allows simulating any ratio of the components of true stress field on specimens with a shape close to the cubic, with a side of the cube of 51-58 mm (Fig. 1).

Tests were conducted on specimens of coal grade "C", seam $d_{4}$ at Pokrovske mine. The "generalized compression" stress state $\left(\mu_{\sigma}=-1, \sigma_{2}=\sigma_{3}=3.5 \mathrm{MPa}, \sigma_{1}\right.$ was simulated to the destruction of specimens, where $\mu_{\sigma}$ is the Lode-Nadai coefficient, $\sigma_{1}, \sigma_{2}, \sigma_{3}$ is the principal stresses, MPa).

General view of the destroyed specimen with failed surfaces axial to $\sigma_{1}$ is shown in Fig. 2. The maximum strains were implemented in the direction of $\sigma_{3}$ (right). From the fracture pattern, crack orientation relative to the prevailing level of the principal stress $\sigma_{1}$ can be seen. The maximum density of cracks and their maximum size are observed directly at the plate test machine with $\sigma_{3}$, indicating a nonlinear deformation of the specimen, such as cracks are the result of inhomogeneous deformation.

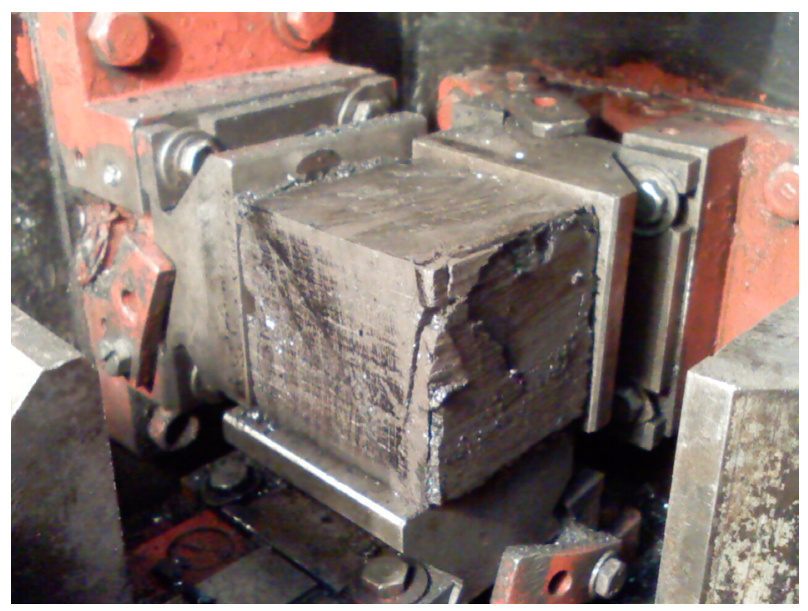

Fig. 1. The coal specimen in the chamber UCTC

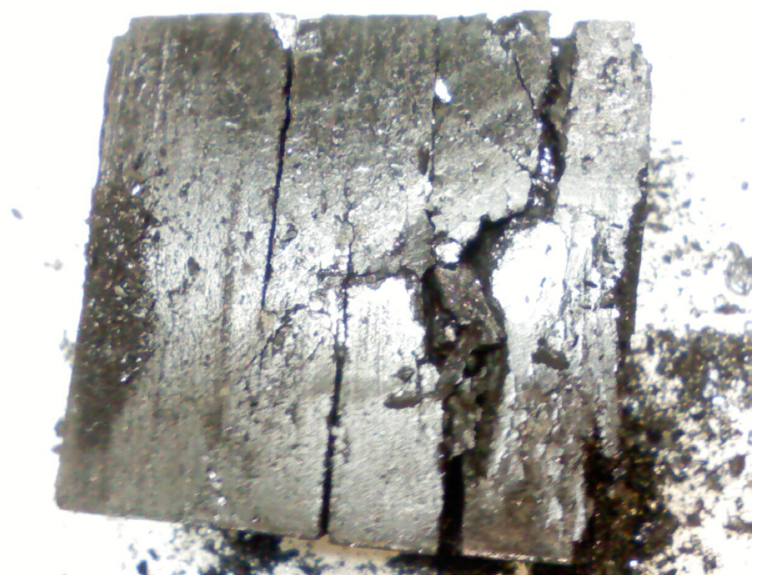

Fig. 2. Coal specimen destroyed in terms of generalized compression 
Simulation numerical modeling was conducted using the finite element method (FEM), which was implemented in the Ansys Inc software. The finite elements model was created in a scale of $1: 1$.

The finite elements had the form of parallelepipeds, due to the shape of the model. A cube-shaped coal specimen with sides of $55 \mathrm{~mm}$ was modeled. Three cube faces with one top were tightly fixed not to move in three mutually perpendicular directions along the respective axes. It simulated stationary plates of the test machine (Fig. 1).

On the free faces of the cube there was discretely added stress that corresponded to the actual load on the pressure plates of UCTC during the physical experiment. The task was solved in 10 steps. During the FEM calculation, movement of cubic specimen faces at every step of loading was obtained. The general view of the finite-element model with the plotted vertical (maximum) deformation, axial to $\sigma_{1}$ is shown in Fig. 3

The numerical experiment under the same load program was carried out three times using various deformation models:

1) the basic isotropic elastic model. Output: elastic modulus, Poisson's ratio;

2) the basic Drucker-Prager plasticity model. Output data: elastic modulus, Poisson's ratio, cohesion coefficient, internal friction angle, angle of dilation;

3) the Drucker-Prager model moderated by the authors. The model takes into account the anisotropy of the elastic modulus, the Poisson's ratio and the displacement modulus in 3D. Output data: elastic modulus, Poisson's ratio, shear modulus, cohesion coefficient, internal friction angle, dilatation angle.

In calculations, the angle of dilatation was assumed to be the limit, which was equal to the angle of internal friction of coal.

Research results and their discussion. The example of visualizing numerical calculation model for the Drucker-Prager model is shown in Fig. 4. The figure shows the negative values of the deformations of axial action axis $\sigma_{1}$ (vertical axis), and the growth of its dimensions in the directions $\sigma_{2}$ and $\sigma_{3}$, which coincides with the actual pattern of deformation.

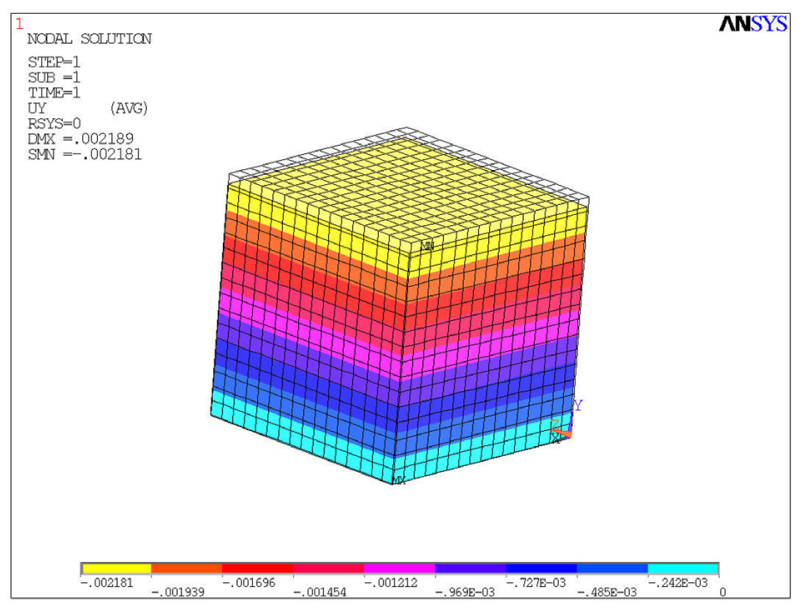

Fig. 3. Model of a coal specimen with a grid of finite elements, combined with a picture of vertical deformations, axial to maximum principal stresses $\sigma_{1}$

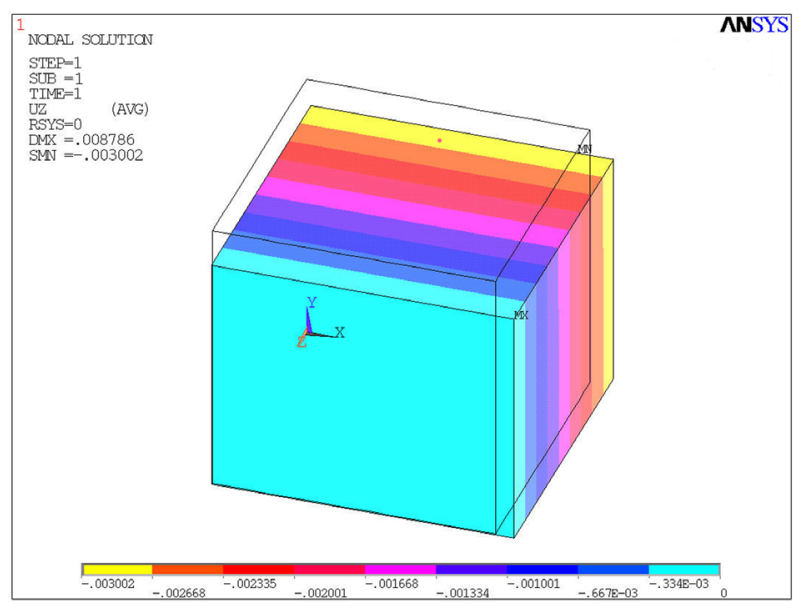

Fig. 4. Pictures of deformations in simulation modeling axial to $\sigma_{3}$

The view of the right model (Fig. 4) corresponds to the front side of the specimen destroyed in Fig. 2, the vertical axis corresponds to the direction of the prevailing principal stress $\sigma_{1}$.

For the analysis of results obtained from the data of the physical experiment and numerical modeling there were calculated stress and deformation tensors, volumetric deformation, average stresses, average deformations, deformations and stress deviator, deformation module, transverse deformation coefficient (Poisson's ratio), volume change energy and shape change energy.

Stress and deformation tensors, $\mathrm{MPa}$

$$
\begin{gathered}
\sigma_{1}=\left(31400 * P_{1}\right) /\left(\left(L_{2}-y\right) *\left(L_{3}-x\right)\right) \\
\sigma_{2}=\left(31400 * P_{2}\right) /\left(\left(L_{1}-z\right) *\left(L_{3}-x\right)\right) ; \\
\sigma_{3}=\left(31400 * P_{3}\right) /\left(\left(L_{1}-z\right) *\left(L_{2}-y\right)\right) ; \\
\varepsilon_{1}=z / L_{1} ; \quad \varepsilon_{2}=y / L_{2} ; \quad \varepsilon_{3}=x / L_{3},
\end{gathered}
$$

where $L_{1}, L_{2}, L_{3}$ are dimensions of the edges of the specimen in the direction of action, respectively $\sigma_{1}, \sigma_{2}$, $\sigma_{3} ; P_{1}, P_{2}, P_{3}$ are pressures on the sensors of the testing machine in the direction of action $\sigma_{1}, \sigma_{2}, \sigma_{3} ; x, y, z$ are displacements of pressure plates - respectively in the direction of action $\sigma_{1}, \sigma_{2}, \sigma_{3}$.

Volumetric deformation

$$
V_{d e f}=\varepsilon_{1}+\varepsilon_{2}+\varepsilon_{3} .
$$

Average stresses, MPa

$$
\sigma_{a v}=\frac{\sigma_{1}+\sigma_{2}+\sigma_{3}}{3}
$$

Average deformations

$$
\varepsilon_{a v}=\frac{\varepsilon_{1}+\varepsilon_{2}+\varepsilon_{3}}{3} .
$$

Stress deviators, $\mathrm{MPa}$

$$
\sigma_{d e 1}=\sigma_{1}-\sigma_{a v} ; \quad \sigma_{d e 2}=\sigma_{2}-\sigma_{a v} ; \quad \sigma_{d e 3}=\sigma_{3}-\sigma_{a v} .
$$

Deformations deviator

$$
\varepsilon_{d e 1}=\varepsilon_{1}-\varepsilon_{a v} ; \quad \varepsilon_{d e 2}=\varepsilon_{2}-\varepsilon_{a v} ; \quad \varepsilon_{d e 3}=\varepsilon_{3}-\varepsilon_{a v} .
$$


Volumetric deformation module, MPa

$$
K=\frac{1}{3} \frac{\sigma_{a v}}{\varepsilon_{a v}} .
$$

Shear modulus, MPa

$$
G=\frac{1}{2} \sqrt{\frac{\sigma_{1} \sigma_{2}+\sigma_{2} \cdot \sigma_{3}+\sigma_{1} \cdot \sigma_{3}}{\varepsilon_{1} \cdot \varepsilon_{2}+\varepsilon_{2} \cdot \varepsilon_{3}+\varepsilon_{1} \cdot \varepsilon_{3}}} .
$$

Deformation module (Young's modulus), MPa

$$
E=\frac{9 K \cdot G}{3 K+G} .
$$

Transverse deformation coefficient (Poisson's ratio)

$$
v=\frac{3 R-2 G}{6 K+2 G}
$$

Volume change energy, $\mathrm{MJ} / \mathrm{m}^{3}$

$$
A_{v}=\left(\sigma_{1}+\sigma_{2}+\sigma_{3}\right) 2 / 18 K \text {. }
$$

Shape change energy, $\mathrm{MJ} / \mathrm{m}^{3}$

$$
\begin{aligned}
A_{f}=\left[\left(\sigma_{1}-\right.\right. & \left.\left.\sigma_{2}\right) 2+\left(\sigma_{1}-\sigma_{3}\right) 2+\left(\sigma_{2}-\sigma_{3}\right) 2\right] \times \\
& \times(1+v) / 18 K(1-2 v) .
\end{aligned}
$$

The analysis results are demonstrated in Figs. 5, 6. They imply that the most accurate description of the experiment is reached when modeling application with the modified Drucker-Prager model.

From Fig. 5 it should be concluded that the modified Drucker-Prager model is as close as possible to the experimental one. In this case, the volumetric strength for an elastic and modified model is overestimated by 10.9 and $1.6 \%$, respectively. At average stresses of $35 \mathrm{MPa}$ in Drucker-Prager models, a typical change in the angle of inclination of the load curve is deformation, in accordance with actual experimental results. For an elastic model, the dependence remains linear over the entire load path.

From Fig. 6 it follows that the use of an elastic model of deformation leads to understatement of Young's

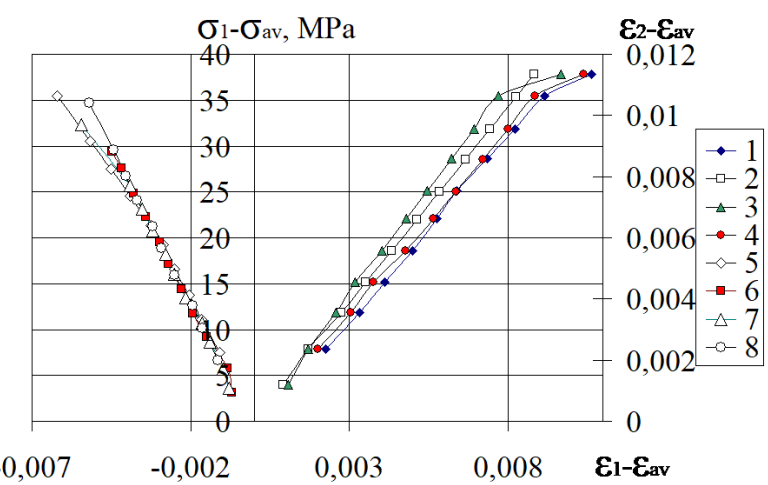

Fig. 5. Relation between stresses and deformations $\left(\mu_{\sigma}=\right.$ $\left.=-1, \sigma_{1} \neq \sigma_{2}=\sigma_{3}\right)$ :

1,5-results of the experiment; $2,3,4,5,7,8$-results of calculation by models, respectively: 2, 6-elastic model; 3 , 7 - Drucker-Prager model; 4, 8 - modified DruckerPrager model

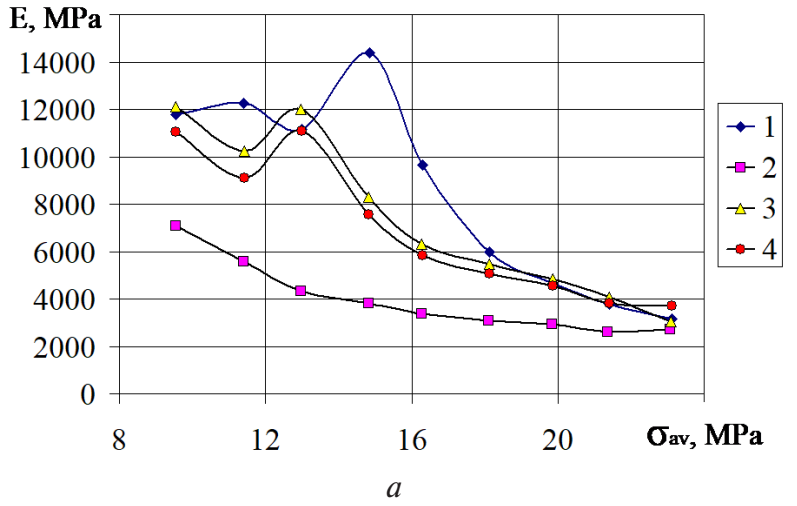

$\mathrm{Av}, \mathrm{MJ} / \mathrm{m}^{3}$

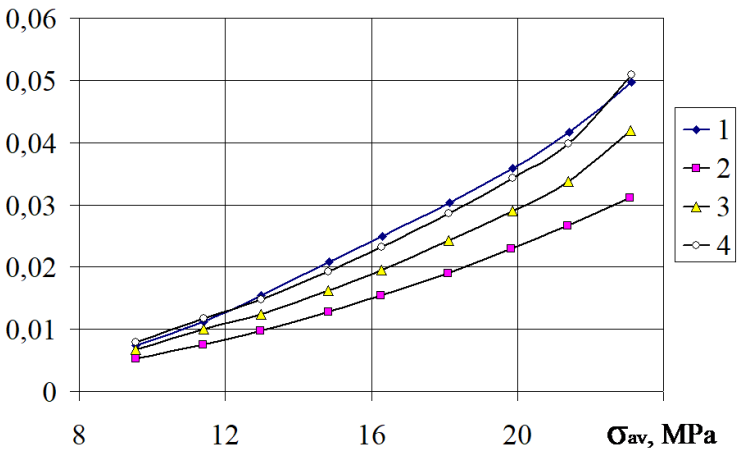

$b$

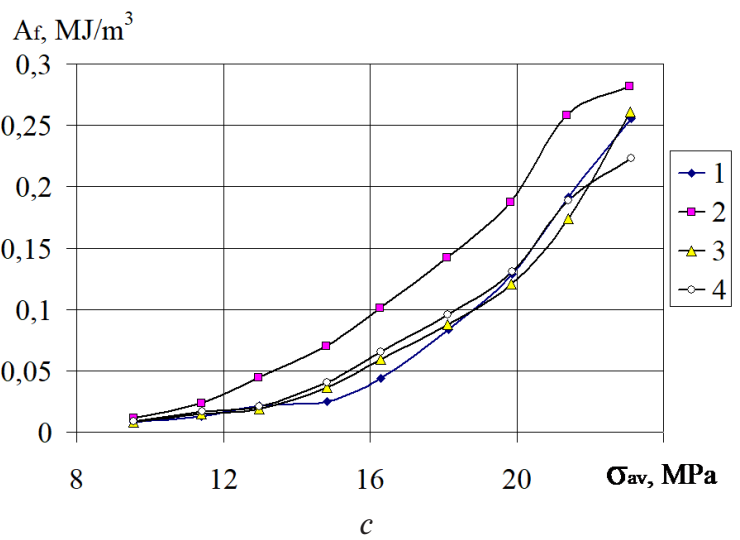

Fig. 6. Dependence on the average stress $\left(\sigma_{\mathrm{cp}}\right)$ :

$a$ - the Young's module $(E) ; b$ - the volume change energy $\left(A_{v}\right) ; c$ - the shape change energy of the specimen $\left(A_{f}\right) ; 1-$ the results of the experiment; $2,3,4$ - the results of calculations by models, respectively: elastic, the basic DruckerPrager model, modified Drucker-Prager model

modulus in individual steps by more than 3 times, the volume change energy - up to $58 \%$, and the energy change of the form - to $35 \%$. Characteristically, simulation using this model does not only cause a significant quantitative error, but fails to reflect some of the quality properties (Fig. 5, a). Simulation using the DruckerPrager basic model describes the experiment more qualitatively, but also is in error of $20-30 \%$ in the mentioned parameters.

A characteristic result is that the modulus of elasticity coincides well with the experiment at the later stages of the load, but the volume change energy and shape 
change energy, on the contrary, coincide at the initial stages.

The estimation of the accuracy of numerical simulation for different deformation models was carried out regarding the dependence of the average stress on average deformations at different load stages in relation to the results of the experiment.

The results show that the error of "the average stressaverage deformation" factor for the elastic model is $33 \%$, for the base model Drucker-Prager - $15 \%$, and for the modified Drucker-Prager model - $0.14 \%$. Moreover, as the maximum principal stress increases, the calculation error for the first two models increases. The solution in an elastic isotropic condition has a permissible variation (up to $10 \%$ ) error with ratio of the maximum principal stress to two others stress up to 5 . For the developed deformation model, at all stages, except the first one, the error is less than $10 \%$.

Conclusions and recommendations for further research. It is established that the use of classical deformation models, with numerical mathematical modeling of geomechanical processes, even in the presence of input data, does not allow describing the behavior of geomaterials in a volumetric stress field with sufficient accuracy, which is natural for rocks.

Modeling using an elastic model does not only cause a quantitative error of more than $30 \%$, but fails to reflect some of the quality properties as well.

Models of geomaterials should take into account the anisotropy of the modulus of elasticity, the shear modulus and the coefficient of transverse deformation, as well as the functional dependence of dilatancy from plastic deformation and coefficient of rigidity.

To model the behavior of coal in true triaxial stressed state, a modified deformation model of Drucker-Prager was created. It takes into account the above-mentioned features of simulation. The results of numerical simulation using the proposed model describe the experimental data most accurately. Further research will be aimed at developing deformation models that describe the behavior of other rocks.

\section{References.}

1. Yasitli, N. E. and Unver, B., 2005. 3D Numerical Modeling of Longwall Mining with Top-Coal Caving. International Journal of Rock Mechanics and Mining Sciences, 42(2), pp. 219-235. DOI: 10.1016/j.ijrmms.2004.08.007. 2. Cheng, Y. M., Wang, J.A., Xie, G.X. and Wei, W. B., 2010. Three-Dimentional Analysis of Coal Barrier Pillars in Tailgate Area Adjacent to the Filly MechAnized Top Coal Caving Mining Face. International Journal of Rock Mechanics and Mining Sciences, 47, pp. 1372-1383. DOI: 10.1016/j.ijrmms.2010.08.008.

3. Yavuz, H., 2004. An Estimation Method for Cover Pressure Re-establishment Distance and Pressure Distribution in the Goaf of Longwall Coal Mines. International Journal of Rock Mechanics and Mining Sciences, 41, pp. 193-205. DOI: 10.1016/S1365-1609(03)00082-0.

4. Ju, M., Li, X., Yao, Q., Li, D., Chong, Z. and Zhou, J., 2015. Numerical investigation into effect of rear barrier pillar on stress distribution around a long- wall face. Journal of Central South University, 22(11), pp. 4372-4384. DOI: 10.1007/s11771-015-2986-8.

5. Sakhno, I. G., 2012. Numeral design of geomechanical processes taking into account their non-linearity, Ground control in mining, 20-21, pp. 57-67. Available at: <http://ea.donntu.edu.ua/bitstream/123456789/26 465/1/\%d0\%a1\%d0\%b0\%d1\%85\%d0\%bd\%d0\%be. pdf $>$ [Accessed 05 November 2017].

6. Murakami, A., Arimoto, S., Setsuyasu, T. and Nishiyama, T., 2005. Mesh-Free Method for Predicting the Behavior of Saturated Soil. In: Geomechanics. Testing, Modelling, and Simulation. pp. 664-672. DOI: 10.1061/40797(172)39.

7. Ceccato, Fr. and Simonini, P., 2016. Granular Flow Impact Forces on Protection Structures: MPM Numerical Simulations with Different Constitutive. Models Procedia Engineering, 158, pp. 164-169. DOI: 10.1016/j. proeng.2016.08.423.

8. Robert, D. J., Soga, K. and Britto, A.M., 2015. Soil Constitutive Models to Simulate Pipeline-soil Interaction Behaviour. In: International Conference on Geotechnical Engineering ICGE Colombo. pp. 347-350.

9. Zhu, W. C. and Tang, C.A., 2004. Micromechanical model for simulating the fracture process of rock. Rock Mechanics and Rock Engineering, 37(1), 25-56.

10. Jaime, M. C., Zhou, Y., Lin, J.-S. and Gamwo, I. K., 2015. Finite element modeling of rock cutting and its fragmentation process. International Journal of Rock Mechanics and Mining Sciences, 80, pp. 137-146.

11. Öztekin, E., Pul, S. and Hüsem, M., 2016. Experimental determination of Drucker-Prager yield criterion parameters for normal and high strength concretes under triaxial compression. Construction Building Materials, 112, pp. 725-732.

12. Jiang, J-F. and Wu, Yu-F., 2012. Identification of material parameters for Drucker-Prager plasticity model for FRP confined circular concrete columns. International Journal of Solids and Structures, 49(3-4), pp. 445-456. DOI: 10.1016/j.ijsolstr.2011.10.002.

13. Karabinis, A. I. and Rousakis, T. C., 2002. Concrete confined by FRP material: a plasticity approach. Engineering Structures, 24, pp. 923-932. DOI: 10.1016/ S0141-0296(02)00011-1.

14. Molodetskyi, A. V. and Codeberg, D. S., 2011. Mechanical characteristics of coal at different types of stress state, Transactions of Kremenchuk Mykhailo Ostrohradskyi National University, 4(69), pp. 107-110. Available at: <http://www.kdu.edu.ua/statti/2011-4-1(69)/107.pdf> [Accessed 24 October 2017].

15. Sergienko, L. V., Gladkaya, E. V. and Molodetskyi, A. V., 2015. Analysis of coal breaking mechanism under the conditions modelling stress-and-strain state of an accompanying-bed while in of mining work, Geotechnical Mechanics, 124, pp. 106-114.

\section{Ідентифікація параметрів матеріалів при чисельному моделюванні поведінки гірських порід у нерівнокомпонентному полі напружень}

\author{
І. Г. Сахно ${ }^{1}$, А. В. Молодецький ${ }^{2}$, С. В. Сахно ${ }^{1}$
}


1 - Державний вищий навчальний заклад „Донецький національний технічний університет“", м. Покровськ, Україна, e-mail: ivan.sakhno@donntu.edu.ua

2 - Інститут фізики гірничих процесів НАН України, м. Дніпро, Україна

Мета. Розробка модифікованої моделі геоматеріалів для чисельного моделювання поведінки гірських порід у нерівнокомпонентному полі напружень.

Методика. Дослідження проведено на зразках вугілля марки „К“. Вхідні параметри матеріалів для базових моделей при моделюванні методом кінцевих елементів узяті з фізичного експерименту. Експеримент проведено на установці нерівнокомпонентного тривісного стиснення. Наведені результати порівняльних досліджень поведінки гірських порід у нерівнокомпонентному полі напружень експериментальним методом і чисельним математичним моделюванням. Моделювання проведене методом кінцевих елементів у програмному комплексі Ansys. Результати випробувань на міцність зразків вугілля в умовах узагальненого стиснення прийняті в якості властивостей in-situ.

Результати. Встановлено, що використання класичних деформаційних моделей - пружної моделі та Друкера-Прагера - при чисельному математичному моделюванні геомеханічних процесів дає похибку при описанні поведінки геоматеріалів в об'ємному полі напружень 30-15\% відносно експерименту. При цьому моделювання з використанням пружної моделі не тільки дає суттєву кількісну похибку, але й не відображає якісно залежності модуля Юнга й модуля об’ємного стиснення від середніх напружень на всіх етапах навантаження. Для адекватного імітування моделі геоматеріалів мають ураховувати анізотропію модуля пружності, модуля зсуву й коефіцієнта поперечної деформації, а також функціональну залежність ділатансіі від пластичної деформації й коефіцієнта жорсткості.

Наукова новизна. Модифікована модель Друкера-Прагера шляхом урахування анізотропії властивостей вугілля. За залежністю „середні напруження - середні деформації“ похибка розрахунку для пружної моделі становить 33 \%, для базової моделі Друкера-Прагера - 15 \%, а для модифікованої моделі Друкера-Прагера - 0,14\%.

Практична значимість. Використання результатів дослідження дозволяє підвищити точність прогнозу напружено-деформованого стану геомеханічних об'єктів.

Ключові слова: метод кінцевих елементів, моделювання геоматеріалів, пружна модель, модель Друкера-Прагера, напруження, деформації

\section{Идентификация параметров материалов при численном моделировании поведения горных пород в неравнокомпонентном поле напряжений}

\author{
И. Г. Сахно , А. В. Молодещкий ${ }^{2}$, С. В. Сахно ${ }^{1}$
}

1 - Государственное высшее учебное заведение „Донецкий национальный технический университет“", г. Покровск, Украина, e-mail: ivan.sakhno@donntu.edu.ua 2 - Институт физики горных процессов НАН Украины, г. Днепр, Украина

Цель. Разработка модифицированной модели геоматериалов для численного моделирования поведения горных пород в неравнокомпонентном поле напряжений.

Методика. Исследование проведено на образцах угля марки „К“. Входные параметры материалов для базовых моделей при моделировании методом конечных элементов взяты из физического эксперимента на угольных образцах. Эксперимент проведен на установке неравнокомпонентного трехосного сжатия. Приведены результаты сравнительных исследований поведения горных пород в неравнокомпонентном поле напряжений экспериментальным методом и численным математическим моделированием. Моделирование проведено методом конечных элементов в программном комплексе Ansys. Результаты испытаний на прочность образцов угля в условиях обобщенного сжатия принято в качестве свойств in-situ.

Результаты. Установлено, что использование классических деформационных моделей - упругой модели и модели Друкера-Прагера - при численном математическом моделировании геомеханических процессов дает погрешность при описании поведения геоматериалов в объемном поле напряжений 30-15\% относительно эксперимента. При этом моделирование с использованием упругой модели не только дает существенную количественную ошибку, но и не отражает качественно зависимости модуля Юнга и модуля объемного сжатия от средних напряжений на всех этапах нагрузки. Для адекватного имитирования модели геоматериалов должны учитывать анизотропию модуля упругости, модуля сдвига и коэффициента поперечной деформации, а также функциональную зависимость дилатансии от пластической деформации и коэффициента жесткости.

Научная новизна. Модифицирована модель Друкера-Прагера путем учета анизотропии свойств угля. По зависимости „средние напряжения средние деформации“ погрешность расчета для упругой модели составляет $33 \%$, для базовой модели Друкера-Прагера - 15 \%, а для модифицированной модели Друкера-Прагера - 0,14\%.

Практическая значимость. Использование результатов исследования позволяет повысить точность прогноза напряженно-деформированного состояния геомеханических объектов.

Ключевые слова: метод конечных элементов, моделирование геоматериалов, упругая модель, модель Друкера-Прагера, напряжения, деформации

Рекомендовано до публікації докт. техн. наук О. В. Вовною. Дата надходження рукопису 18.09.17. 